\title{
SEBA NURAINI
}

\begin{abstract}
ABSTRAK
Discovery adalah proses mental dimana siswa memampu mengasimilasikan sesuatu konsep atau prinsip.Yang dimaksudkan dengan proses mental tersebu tantara lain ialah:mengamati,mencerna, mengerti, menggolong-golongkan, membuat dugaan, menjelaskan, mengukur membuat kesimpulan.discovery learning, ialah suatu cara mengajar yang melibatkan siswa dalam proses kegiatan mental melalui tukar pendapat,dengan diskusi,seminar,membaca sendiridan mencoba sendiri. Agar anak dapat belajar sendiri.Prestasi belajar adalahhasilyang dicapai (dilakukan,dikerjakan),dalam hal ini prestasi belajar merupakan hasilpekerjaan, hasil penciptaan oleh seseorang yang diperoleh dengan ketelitian kerja serta perjuangan yang membutuhkan pikiran.Tujuan Penelitian ini adalah Untuk Meningkatkan Prestasi Belajar Siswa Pada Mata Pelajaran PKN Dengan Metode Discovery di Kelas VII SMP Negeri 1 Pancur Batu Tahun Pelajaran 2015/2016. Berdasarkan penelitian yang dilakukan maka diperoleh hasil pada Siklus I nilairata-rata prestasi belajar siswa adalah 70,00 dan ketuntasan belajar mencapai siklus 67,57\% atauada 25 siswa dari35 siswa sudah tuntas belajar. Siklus II nilai rata-rata prestasi belajar siswa adalah 77,03dan ketuntasan belajar mencapai78,38\%atau ada 29 siswa dari35 siswa sudah tuntasbelajarSiklus III nilai rata-rata tes formatif sebesar83,24dan dari35 siswa yang telah tuntas sebanyak33 siswa dan siswa belum mencapai ketuntasan belajar. Melalui hasil peneilitianini menunjukkan bahwa pembelajaran penemuan (discovery) memilikidampak positif dalam meningkatkan prestasi belajar siswa.Hal ini dapat dilihat dari semakin mantapnya pemahaman siswa terhadap materiyang disampaikan guru(ketuntasan belajar meningkat dari sklusI,II,danIII)yaitu masing-masing 67,57\%,78,38\%,dan89,19\%.Pada siklus III ketuntasan belajar siswa secara klasikal telah tercapai.
\end{abstract}

Kata kunci:Prestasi belajar, MetodeDiscovery, Pembelajaran IPA

\section{PENDAHULUAN}

Pendidikan merupakan suatu upaya untuk meningkatkan sumber daya manusia.

Menciptakan manusia yang cerdas dan maju perlu diimbangi dengan peningkatan mutu pendidikan. Mutu pendidikan sangat erat kaitannya dengan mutu guru. Kunci keberhasilan 

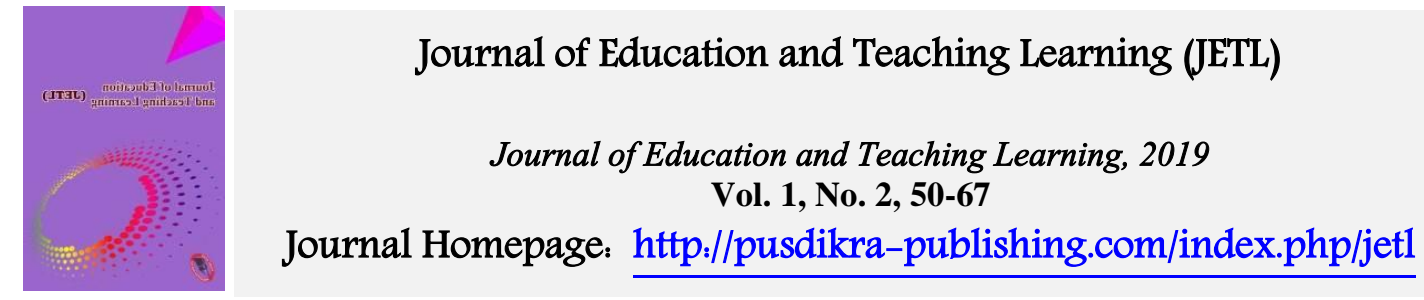

pelaksanaan sangat ditentukan oleh faktor guru sebagai pengelola kegiatan pembelajaran. Namun semua juga tidak terlepas dari kemampuan siswa dari proses pembelajaran berlangsung, dari proses belajar mengajar ini harus kerja sama antara guru dengan murid ini akan menghasilkan hasil yang maksimal dengan meminimalisir kendala yang ada dengan memaksimalkan keunggulan dari keduanya.

Pada hakekatnya kegiatan belajar mengajar adalah suatu proses interaksi atau hubungan timbal balik antara guru dan siswa dalam satuan pembelajaran. Guru sebagai salah satu komponen dalam proses belajar mengajar merupakan pemegang peran yang sangat penting. Guru bukan hanya sekedar penyampai materi saja, tetapi Iebih dan itu guru dapat dikatakan sebagai sentral pembelajaran.

Guru mengemban tugas yang berat untuk tercapainya tujuan pendidikan nasional yaitu meningkatkan kualitas manusia Indonesia, manusia seutuhnya yang beriman dan bertakwa terhadap Tuhan Yang Maha Esa, berbudi pekerti luhur, berkepribadian, berdisiplin, bekerja keras, tangguh, bertanggung jawab, mandiri, cerdas dan terampil serta sehat jasmani dan rohani, juga harus mampu menumbuhkan dan memperdalam rasa cinta terhadap tanah air, mempertebal semangat kebangsaan dan rasa kesetiakawanan sosial. Sejalan dengan itu pendidikan nasional akan mampu mewujudkan manusia-manusia pembangunan dan membangun dirinya sendiri serta bertanggung jawab atas pembangunan bangsa.

Berhasilnya tujuan pembelajaran ditentukan oleh banyak faktor diantaranya adalah faktor guru dalam melaksanakan proses belajar mengajar, karena guru secara langsung dapat mempengaruhi, membina dan meningkatkan kecerdasan serta keterampilan siswa. Untuk mengatasi permasalahan di atas dan guna mencapai tujuan pendidikan secara maksimal, 


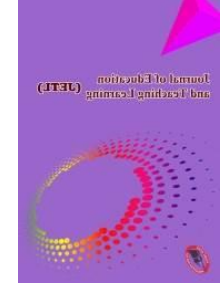

\section{Journal of Education and Teaching Learning (JETL) \\ Journal of Education and Teaching Learning, 2019 \\ Vol. 1, No. 2, 50-67 \\ Journal Homepage: http://pusdikra-publishing.com/index.php/jetl}

peran guru sangat penting dan diharapkan guru memiliki caralmodel mengajar yang balk dan mampu meinilih model pembelajaran yang tepat dan sesuai dengan konsep-konsep mata pelajaran yang akan disampaikan.

Tujuan pendidikan nasional seperti yang terdapat dalam Undang Undang Nomor 2 tahuan 1989 yaitu mencerdaskan kehidupan bangsa dan mengembangkan manusia Indonesia yang beriman dan bertakwa terhadap Tuhan Yang Maha Esa dan berbudi luhur, memiliki pengetahuan dan keterampilan, sehat jasmani dan rohani kepribadian yang mantap dan mandiri serta bertanggung jawab kemasyarakatan bangsa. Tujuan pendidikan nasiona1 sangat luas dan bersifat umum sehingga perlu dijabarkan dalam Tujuan Institusional yang disesuaikan dengan jenis dan tingkatan sekolah yang kemudian dijabarkan lagi menjadi tujuan kurikuler yang merupakan tujuan kurikulum sekolah yang diperinci menurut bidang studi/mata pelajaran atau kelompok mata pelajaran. Tujuan instruksional dijabarkan menjadi Tujuan Pembelajaran Umum dan kemudian dijabarkan lagi menjadi Tujuan Pembelajaran Khusus (TPK).

Dalam mencapai Tujuan Pembelajaran Khusus pada mata pelajaran PKN Terpadu di Sekolah Menengah, khususnya di SMP Negeri 1 Pancur Batu masih banyak mengalami kesulitan. Hal ini terlihat dan masih rendahnya nilai mata pelajaran PKN dibandingkan dengan nilai beberapa mata pelajaran lainnya, dalam hal tersebut di atas perlu pemikiranpemikiran dan tindakan-tindakan yang harus dilalukan agar siswa dalam mempelajari konsepkonsep tidak mengalami kesulitan, sehingga tujuan pembelajaran khusus yang dibuat oleh guru mata pelajaran PKN Terpadu dapat tercapai dengan baik dan hasilnya dapat memuaskan 


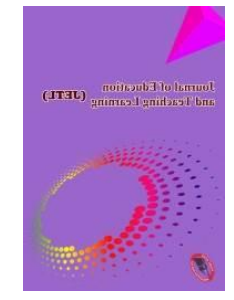

\section{Journal of Education and Teaching Learning (JETL) \\ Journal of Education and Teaching Learning, 2019 \\ Vol. 1, No. 2, 50-67 \\ Journal Homepage: http://pusdikra-publishing.com/index.php/jetl}

semua pihak. Oleh sebab itu penggunaan metode pembelajaran dirasa sangat penting untuk membantu siswa dalam memahami konsep-konsep PKN.

Metode pembelajaran jenisnya beragam yang masing-masing memiliki kelebihan dan kelemahan, maka pemilihan metode yang sesuai dengan topik atau pokok bahasan yang akan diajarkan harus betul-betul dipikirkan oleh guru yang akan menyampaikan materi pelajaran. Penggunaan metode demonstrasi diharapkan dapat meningkatkan hasil belajar siswa dalam proses belajar mengajar sehingga dalam proses belajar mengajar itu aktivitasnya tidak hanya didominasi oleh guru, dengan demikian siswa akan terlibat secara fisik, emosional dan intelektual yang pada gilirannya diharapkan konsep materi PKN dapat dikuasai.

Permasalahan yang timbul karena ketidaktepatan penggunaan metode dalam pembelajaran, senantiasa memberikan arahan bagi peneliti dalam melakukan penelitian yaitu dengan mengubah kebiasaan yang sering dilakukan guru dalam memilih metode yang tepat. Maka, dalam penelitian ini peneliti akan memilih salah satu metode yang dianggap dapat meningkatkan hasil belajar siswa yaitu dengan menggunakan metode demonstrasi.

Metode demonstrasi merupakan metode mengajar dengan cara memperagakan barang, kejadian, aturan, dan urutan melakukan suatu kegiatan, baik secara langsung maupun melalui penggunaan media pengajaran yang relevan dengan pokok bahasan atau materi yang sedang disajikan.

Metode demonstrasi adalah cara menyampaikan materi pembelajaran dengan peragaan, baik dilakukan oleh dirinya atau meminta orang lain untuk memperagakannya. Metode demonstrasi "berguna untuk menunjukkan keterampilan tertentu, memudahkan penjelasan, menghindari verbalisme (banyak omong padahal tidak perlu) dan 


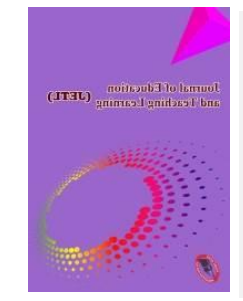

\section{Journal of Education and Teaching Learning (JETL) \\ Journal of Education and Teaching Learning, 2019 \\ Vol. 1, No. 2, 50-67 \\ Journal Homepage: http://pusdikra-publishing.com/index.php/jetl}

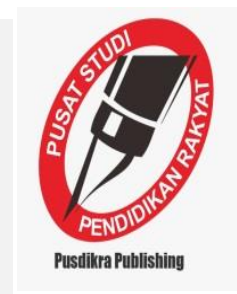

melatih keterampilan."

Bagi siswa SMP penerapan metode demonstrasi sangat penting, karena dapat meningkatkan kualitas intelektual peserta didik baik dari aspek kognitif, afektif dan psikomotorik. Selain itu penggunaan metode demonstrasi diharapkan dapat memberikan pengaruh positif bagi siswa dan mampu meningkatkan hasil belajar siswa.

Kesulitan yang sering dialami siwa dalam memahami pelajaran PKN di SMP Negeri 1 Pancur Batu disebabkan berbagai faktor antara lain:

a) Motivasi belajar PKN Terpadu siswa yang rendah,

b) Kemampuan siswa dalam memahami pelajaran masih rendah,

c) Model pembelajaran yang diterapakan guru di kelas masih terpusat pada guru dan monoton sehingga terkesan membosankan.

Berdasarkan pengalaman yang diadapi didalam proses pembelajaran PKN yang tidak aktif maka guru berusaha mencarikan metode pembelajaran lain, sehingga pembelajaran lebih bermakna dan lebih berkualitas. Penerapan metode demonstrasi merupakan salah satu upaya yang dilakukan pendidik dalam upaya peningkatan hasil belajar siswa pada pembelajaran PKN di kelas VII-2 SMPN 1 Pancur Batu Tahun 2014/2015.

Penerapan metode demonstrasi dengan tujuan untuk meningkatkan hasil belajar pada siswa kelas VII-2 SMPN 1 Pancur Batu pada pembelajaran PKN juga diharapkan dapat memotivasi siswa untuk lebih aktif dalam proses belajar mengajar. Berdasarkan latar belakang di atas maka judul penelitian ini adalah : "Meningkatkan Hasil Belajar Siswa Pada Mata Pelajaran PKN Dengan Metode Demonstrasi di Kelas VII-2 SMP Negeri 1 Pancur Batu Tahun Pelajaran 2014-2015". 
Journal of Education and Teaching Learning (JETL)

Journal of Education and Teaching Learning, 2019

Vol. 1, No. 2, 50-67

Journal Homepage: http://pusdikra-publishing.com/index.php/jetl

\section{METODE PENELITIAN}

Lokasi dan Waktu Penelitian ini dilaksanakan di kelas VII - 2 SMP Negeri 1 Pancur Batu Kab. Deli Serdang Tahun Pelajaran 2014/2015 yang berlokasi di Jamin Ginting Pancur Batu, BARU, Kecamatan Pancur Batu, Kabupaten Deli Serdang Sumatera Utara. Waktu penelitian dilaksanakan pada bulan Januari sampai Mei semester Genap 2014/2015. Subjek penelitian dalam PTK ini adalah siswa kelas VII $\mathbf{- 2}$ SMP Negeri 1 Pancur Batu Kab. Deli Serdang tahun pelajaran 2014/2015 yang berjumlah 45 orang, dengan jumlah siswa laki-laki 19 dan jumlah siswa perempuan 26 orang. Metode Penelitian dalam yang diterapkan dalam Penelitian ini adalah PTK (Penelitian Tindakan Kelas) yang mempunyai tahapan-tahapan yaitu perencanaaa, tindakan, observasi, refleksi.

Teknik pengumpulan data pada penelitian ini adalah tes dan observasi. Tes adalah alat untuk memperoleh sejauh mana kemampuan siswa dan melihat tingkat keberhasilan siswa dan suatu materi ajar yang disampaikan berupa objektiftes (pilihan ganda). Observasi yang dilakukan merupakan pengamatan terhadap seluruh kegiatan pengajaran yang dilakukan dan awal tindakan sampai berakhirnya pelaksanaan tindakan.

Adapun cara menganalisis data adalah dengan memakai analisa data persentase dan kuantitas data. Analisa Persentase dilakukan dengan mengetahul berhasil atau tidaknya tindakan yang dilakukan dengan menggunakan persentase sebagai berikut:

$$
P=\frac{f}{n} \times 100 \%
$$

$\mathrm{P}=$ angka prestasi

$\mathrm{F}=$ jumlah siswa yang mengalami perubahan 
$\mathrm{n}=$ jumlah seluruh siswa

Kriteria ketuntasan belajar siswa pada penelitian tindakan kelas ini yalta sebagai berikut:

$0 \leq \mathrm{P} \leq 65$ Belum tuntas

$70 \leq \mathrm{P} \leq 100$ Tuntas

Sumber: Penelitian Tindakan Kelas Untuk Guru SMP, SMA, dan SD : Aqib

Analisa data dilakukan dengan perbandingan persentase guna menilai seberapa efektifkah hasil belajar siswa dengan menggunakan alat dan bahan bahan demontrasi path mata pelajaran PKN sebagai berikut:

1. Melakukan pengecekan data yang sudah masuk.

2. Melakukan penapsiran.

3. Menyimpulkan apakah tindakan pembelajaran ini terjadi peningkatan hasil belaiar siswa atau tidak berdasarkan hasil obsevasi.

4. Tahap tindak lanjut yalta merumuskan iangkah-langkah perbaikan untuk siklus pembelajaran berikutnya.

5. Penarikan kesimpulan.

\section{PEMBAHASAN HASIL PENELITIAN}

\section{Deskripsi Awal Penelitian}

Data penelitian yang diperoleh berupa data observasi berupa pengamatan pengelolaan pembelajaran demonstrasi dan pengamatan aktivitas siswa dan guru pada akhir pembelajaran, pada setiap siklus.

Data lembar observasi diambil dari dua pengamatan yaitu data pengamatan 
Journal of Education and Teaching Learning (JETL)

Journal of Education and Teaching Learning, 2019

Vol. 1, No. 2, 50-67

Journal Homepage: http://pusdikra-publishing.com/index.php/jetl

pembelajaran demonstrasi yang digunakan untuk mengetahui pengaruh penerapan metode pembelajaran demonstrasi dalam meningkatkan prestasi. Data tes formatif untuk mengetahui peningkatan prestasi belajar siswa setelah diterapkan pembelajaran demonstrasi.

Pada awal pembelajaran sebelum metode demontrasi digunakan maka kondisi siswa kelas VII-2 banyak yang tidak memperhatikan pelajaran PKN karena sudah ada di benak untuk merasa kesulitan dalam pembelajaran PKN. Sebagian besar siswa acuh tak acuh dan merasa sulit dalam mengerjakan soal-soal yang diberikan oleh guru. Susasana membosankan tersebut ternyata berdampak pada hasil belajar siswa, dari hasil ulangan akhir semester 1 jumlah ketuntasan belajar siswa belum mencapai ketuntasan secara klasikal.

Tabel 4.1 Rata-rata Hasil Ketuntasan Pelajaran PKN Kelas VII-2 Tahun Pelajaran 2014/2015

\begin{tabular}{|l|c|c|c|}
\hline \multicolumn{1}{|c|}{ Siswa } & Nilai & Jumlah Siswa & Persentase \\
\hline Jumlah Siswa tuntas & $\geq 65$ & 13 & $29 \%$ \\
\hline Jumlah Siswa tidak tuntas & $\leq 65$ & 32 & $71 \%$ \\
\hline Jumlah & 45 siswa & $100 \%$ \\
\hline
\end{tabular}

Sumber : SMP Negeri 1 Pancur Batu

Data tersebut menunjukkan minimnya nilai siswa terhadap mata pelajaran PKN. Rendahnya ketuntasan hasil belajar tersebut dikarenakan, siswa tidak dapat menjawab soal yang diberikan dengan baik padahal bahan tes sudah diajarkan dan materi berasal dari buku paket yang dimiliki oleh semua siswa. Permasalahan sebenarnya terjadi pada saat proses belajar mengajar ketika penyampaian meteri yang membosankan sehingga berdampak pada ketidaktertarikan siswa terhadap materi yang diajarkan. Hal inilah yang menyebabkan hasil belajar siswa rendah 
Journal of Education and Teaching Learning (JETL)

Journal of Education and Teaching Learning, 2019

Vol. 1, No. 2, 50-67

Journal Homepage: http://pusdikra-publishing.com/index.php/jetl

\section{Kondisi Siklus I dan II}

Tahap Perencanaan, Pada tahap ini peneliti mempersiapkan perangkat pembelajaran yang terdiri dari rencana pelajaran 1 , LKS 1 , soal tes formatif 1 , dan alat- alat pengajaran yang mendukung.

Tahap Kegiatan dan Pelaksanaan, Pelaksanaan kegiatan belajar mengajar untuk siklus I dilaksanakan pada tanggal 10 Januari 2015 di kelas VII-2 dengan jumlah siswa 45 siswa. Dalam hal ini peneliti bertindak sebagai guru. Adapun proses belajar mengajar mengacu pada rencana pelajaran yang telah dipersiapkan. Pengamatan (observasi) dilaksanakan bersamaan dengan pelaksanaan belajar mengajar.

Pada akhir proses belajar mengajar siswa diberi tes formatif I dengan tujuan untuk mengetahui tingkat keberhasilan siswa dalam proses belajar mengajar yang telah dilakukan. Adapun data hasil penelitian pada siklus I adalah sebagai berikut:

Tabel 4.2 Pengelolan Pembelajaran Pada Siklus I

\begin{tabular}{|c|c|c|c|c|}
\hline \multirow{2}{*}{ No } & \multirow{2}{*}{ Aspek yang diamati } & \multicolumn{2}{|c|}{ Penilaian } & \multirow{2}{*}{$\begin{array}{l}\text { Rata } \\
\text {-rata }\end{array}$} \\
\hline & & $\mathrm{P} 1$ & $\mathrm{P} 2$ & \\
\hline \multirow{12}{*}{ I } & Pengamatan KBM & & & \\
\hline & A. Pendahuluan & & & \\
\hline & 1. Memotivasi siswa & 3 & 4 & 4 \\
\hline & 2. Menyampaikan tujuan pembelajaran & 4 & 3 & 3 \\
\hline & B. Kegiatan Inti & & & \\
\hline & 1. Mendiskusikan langkah-langkah kegiatan bersama & 4 & 4 & 4 \\
\hline & siswa & 3 & 3 & 3 \\
\hline & 2. Membimbing siswa melakukan kegiatan & & & \\
\hline & $\begin{array}{l}\text { 3. Membimbing siswa mendiskusikan hasil kegiatan } \\
\text { dalam kelompok }\end{array}$ & 3 & 3 & 3 \\
\hline & $\begin{array}{l}\text { 4. Memberikan kesempatan pada siswa untuk } \\
\text { mempresentasikan hasil kegiatan belajar mengajar } \\
\text { 5. Membimbing siswa merumuskan }\end{array}$ & 3 & 3 & 3 \\
\hline & C. Penutup & & & \\
\hline & 1. Membimbing siswa membuat rangkuman & 3 & 3 & 3 \\
\hline II & Pengelolaan Waktu & 3 & 3 & 3 \\
\hline
\end{tabular}




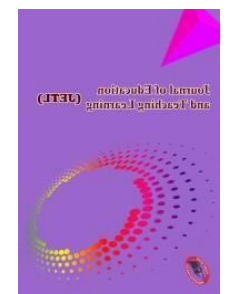

Journal of Education and Teaching Learning (JETL)

Journal of Education and Teaching Learning, 2019

Vol. 1, No. 2, 50-67

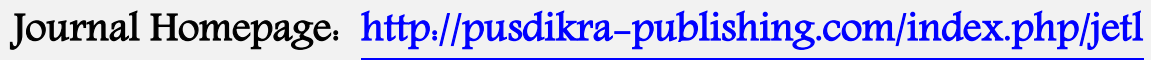

\begin{tabular}{|r|c|r|r|r|}
\hline \multirow{2}{*}{ III } & Antusiasme Kelas & & \\
& 1. Siswa Antusias & 3 & 3 & 3 \\
\hline 2 Gurw Antusias & 2 & 2 & 2 \\
\hline
\end{tabular}

Keterangan: Nilai : Kriteria

1 : Tidak Baik

2 : Kurang Baik

3 : Cukup Baik

4 : Baik

Berdasarkan tabel 4.2 di atas aspek-aspek yang mendapatkan kriteria kurang baik adalah memotivasi siswa, menyampaikan tujuan pembelajaran, pengelolaan waktu. Ketiga aspek yang mendapat penilaian kurang baik di atas, merupakan suatu kelemahan yang terjadi pada siklus I. Dan akan dijadikan bahan kajian untuk refleksi dan revisi yang akan dilakukan pada siklus II.

Hasil observasi berikutnya adalah aktivitas guru dan siswa seperti pada tabel berikut.

Tabel 4.3. Aktivitas Guru Dan Siswa Pada Siklus I

\begin{tabular}{|r|l|c|}
\hline No & \multicolumn{1}{|c|}{ Aktivitas Guru yang diamati } & Persentase \\
\hline 1 & Menyampaikan tujuan & 6.77 \\
2 & Memotivasi siswa/merumuskan masalah & 11.00 \\
3 & Mengkaitkan dengan pelajaran berikutnya & 8.30 \\
4 & Menyampaikan materi/langkah-langkah/strategi & 5.50 \\
5 & Menjelaskan materi yang sulit & 17.00 \\
6 & Membimbing dan mengamati siswa dalam menemukan & 21.00 \\
7 & konsep Meminta siswa menyajikan dan mendiskusikan hasil & 11.00 \\
8 & kegiatan Memberikan umpan balik & 13.00 \\
\hline No & \multicolumn{1}{|c|}{ Aktivitas Siswa yang diamati } & Persentase \\
\hline 1 & Mendengarkan/memperhatikan penjelasan guru & 20,63 \\
2 & Membaca buku siswa & 13.29 \\
3 & Bekerja dengan sesama anggota kelompok & 17.75 \\
4 & Diskusi antar siswa/antara siswa dengan guru & 14.38 \\
5 & Menyajikan hasil pembelajaran & 3.96 \\
6 & Mengajukan/menanggapi pertanyaan/ide & 7.25 \\
7 & Menulis yang relevan dengan KBM & 7.75 \\
8 & Merangkum pembelajaran & 6.88 \\
\hline
\end{tabular}




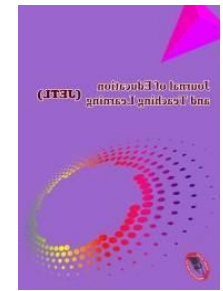

Journal of Education and Teaching Learning (JETL)

Journal of Education and Teaching Learning, 2019

Vol. 1, No. 2, 50-67

Journal Homepage: http://pusdikra-publishing.com/index.php/jetl

Berdasarkan tabel 4.3 di atas tampak bahwa aktivitas guru yang paling dominan pada siklus I adalah membimbing dan mengamati siswa dalam menemukan konsep yaitu masing-masing dan menjelaskan materi yang sulit 21,00 dan 17,00\%. Aktivitas lain yang persentasenya cukup besar adalah memberi umpan balik yaitu 13,00\%. Sedangkan aktivitas siswa yang paling dominan adalah mengerjakan/memperhatikan penjelasan guru yaitu 20,63\%. Aktivitas lain yang persentasenya cukup besar adalah bekerja dengan sesama anggota kelompok, diskusi antar siswa/antara siswa dengan guru, dan membaca buku yaitu masing-masing $17,75 \%, 14,38$ dan $13,29 \%$.

Pada siklus I, secara garis besar kegiatan belajar mengajar dengan metode pembelajaran demonstrasi sudah dilaksanakan dengan baik, walaupun peran guru masih cukup dominan untuk memberikan penjelasan dan arahan karena model tersebut masih dirasakan baru oleh siswa.

Berikutnya adalah rekapitulasi hasil tes formatif siswa seperti terlihat pada tabel berikut.

Tabel 4.4. Rekapitulasi Hasil Tes Siklus I

\begin{tabular}{|c|l|c|}
\hline No & \multicolumn{1}{|c|}{ Uraian } & Hasil Siklus I \\
\hline 1 & Nilai rata-rata tes formatif & 71,00 \\
2 & Jumlah siswa yang tuntas belajar & 39 \\
3 & Persentase ketuntasan belajar & 69,57 \\
\hline
\end{tabular}

Berdasaran Tabel 4.4 dapat dijelaskan bahwa dengan menerapkan metode pembelajaran demonstrasi diperoleh nilai rata-rata prestasi belajar siswa adalah 71,00 dan ketuntasan belajar mencapai $69,57 \%$ atau ada 39 siswa dari 45 siswa sudah tuntas belajar. Hasil tersebut menunjukkan bahwa pada siklus pertama secara klasikal siswa belum 


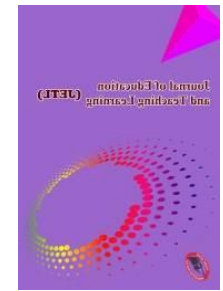

Journal of Education and Teaching Learning (JETL)

Journal of Education and Teaching Learning, 2019

Vol. 1, No. 2, 50-67

Journal Homepage: http://pusdikra-publishing.com/index.php/jetl

tuntas belajar, karena siswa yang memperoleh nilai $\geq 71$ hanya sebesar $69,57 \%$ lebih kecil dari persentase ketuntasan yang dikehendaki yaitu sebesar $85 \%$. Hal ini disebabkan karena siswa masih merasa baru dan belum mengerti apa yang dimaksudkan dan digunakan guru dengan menerapkan metode pembelajaran demonstrasi.

\section{Siklus II}

Tahap perencanaan, Pada tahap ini peneliti mempersiapkan perangkat pembelajaran yang terdiri dari rencana pelajaran 2, LKS 2, soal tes formatif II, dan alat- alat pengajaran yang mendukung.

Tahap kegiatan dan pelaksanaan

kegiatan belajar mengajar untuk siklus II dilaksanakan pada tanggal 10 Maret 2015 di kelas VII-2 dengan jumlah siswa 45 siswa. Dalam hal ini peneliti bertindak sebagai guru. Adapun proses belajar mengajar mengacu pada rencana pelajaran dengan memperhatikan revisi pada siklus I, sehingga kesalahan atau kekurangan pada siklus I tidak terulang lagi pada siklus II. Pengamatan (observasi) dilaksanakan bersamaan dengan pelaksanaan belajar mengajar.

Pada akhir proses belajar mengajar siswa diberi tes formatif II dengan tujuan untuk mengetahui tingkat keberhasilan siswa selama proses belajar mengajar yang telah dilakukan. Instrument yang digunakan adalah tes formatif II. Adapun data hasil penelitian pada siklus II adalah sebagai berikut.

Tabel 4.5. Pengelolaan Pembelajaran Pada Siklus II

\begin{tabular}{|l|l|l|l|l|}
\hline \multirow{2}{*}{ No } & \multirow{3}{*}{ Aspek yang diamati } & \multicolumn{2}{|c|}{ Penilaian } & Rata \\
\cline { 3 - 4 } & P1 & P2 & -rata \\
\hline
\end{tabular}


Journal of Education and Teaching Learning (JETL)

Journal of Education and Teaching Learning, 2019

Vol. 1, No. 2, 50-67

Journal Homepage: http://pusdikra-publishing.com/index.php/jetl

\begin{tabular}{|c|c|c|c|c|}
\hline \multirow{12}{*}{ I } & $\begin{array}{l}\text { Pengamatan KBM } \\
\text { A. Pendahuluan } \\
\text { 1. Memotivasi siswa }\end{array}$ & 3 & 3 & 3 \\
\hline & $\begin{array}{l}\text { A Manvamnaikan twiwan nombaloiaran } \\
\text { B. Kegiatan Inti }\end{array}$ & 2 & 3 & \\
\hline & 1. Mendiskusikan langkah-langkah kegiatan & 3 & 3 & 3 \\
\hline & bersama siswa & 4 & 4 & 4 \\
\hline & 2. Membimbing siswa melakukan kegiatan & & & \\
\hline & $\begin{array}{l}\text { 3. Membimbing siswa mendiskusikan hasil } \\
\text { kegiatan dalam kelompok }\end{array}$ & 4 & 4 & 3 \\
\hline & 4. Memberikan kesempatan pada siswa untuk & 4 & 4 & 4 \\
\hline & mengajar & 3 & 3 & 3 \\
\hline & 5 Membimbino siswa merumuskan & & & \\
\hline & C. Penutup & & & \\
\hline & 1. Membimbing siswa membuat rangkuman & 3 & 4 & 3,5 \\
\hline & 2. Memberikan evaluasi & 4 & 3 & 4 \\
\hline II & Pengelolaan Waktu & 3 & 3 & 2 \\
\hline \multirow{3}{*}{ III } & Antusiasme Kelas & & & \\
\hline & 1. Siswa Antusias & 3 & 3 & 3,5 \\
\hline & 2. Guru Antwsias & 4 & 4 & 4 \\
\hline & Jumlah & 41 & 41 & 41 \\
\hline
\end{tabular}

$\begin{array}{ll}\text { Keterangan : } & \text { Nilai : Kriteria } \\ & 1: \text { Tidak Baik } \\ & 2: \text { Kurang Baik } \\ & 3: \text { Cukup Baik } \\ & 4: \text { Baik }\end{array}$

Tabel 4.5 tampak aspek-aspek yang diamati pada kegiatan belajar mengajar (siklus II) yang dilaksanakan oleh guru dengan menerapkan metode pembelajaran demonstrasi mendapatkan penilaian yang cukup baik dari pengamat. Maksudnya dari seluruh penilaian tidak terdapat nilai kurang. Namum demikian penilaian tersebut belum merupakan hasil yang optimal, untuk itu ada beberapa aspek yang perlu mendapatkan perhatian untuk penyempurnaan penerapan pembelajaran selanjutnya. Aspek-aspek tersebut adalah memotivasi siswa, membimbing siswa merumuskan kesimpulan/menemukan konsep, dan pengelolaan waktu.

Dengan penyempurnaan aspek-aspek di atas dalam penerapan metode pembelajaran 


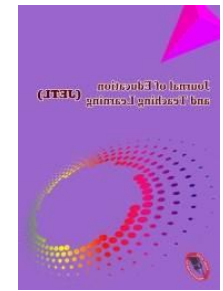

Journal of Education and Teaching Learning (JETL)

Journal of Education and Teaching Learning, 2019

Vol. 1, No. 2, 50-67

Journal Homepage: http://pusdikra-publishing.com/index.php/jetl

demonstrasi diharapkan siswa dapat menyimpulkan apa yang telah mereka pelajari dan mengemukakan pendapatnya sehingga mereka akan lebih memahami tentang apa yang telah mereka lakukan. Berikut disajikan hasil observasi aktivitas guru dan siswa.

Tabel 4.6 Aktivitas Guru Dan Siswa Pada Siklus II

\begin{tabular}{|r|l|c|}
\hline No & \multicolumn{1}{|c|}{ Aktivitas Guru yang diamati } & Persentase \\
\hline 1 & Menyampaikan tujuan & 6.67 \\
2 & Memotivasi siswa/merumuskan masalah & 7.67 \\
3 & Mengkaitkan dengan pelajaran berikutnya & 6.67 \\
4 & Menyampaikan materi/langkah-langkah/strategi & 11.67 \\
5 & Menjelaskan materi yang sulit & 11.67 \\
6 & Membimbing dan mengamati siswa dalam menentukan & 24.00 \\
7 & konsep Meminta siswa menyajikan dan mendiskusikan hasil & 8.33 \\
8 & kegiatan Memberikan umpan balik & 16.67 \\
\hline No & \multicolumn{1}{|c|}{ Aktivitas Siswa yang diamati } & Persentase \\
\hline 1 & Mendengarkan/memperhatikan penjelasan guru & 17.81 \\
2 & Membaca buku siswa & 14.26 \\
3 & Bekerja dengan sesama anggota kelompok & 19.79 \\
4 & Diskusi antar siswa/antara siswa dengan guru & 13.96 \\
5 & Menyajikanhasil pembelajaran & 5.00 \\
6 & Mengajukan/menanggapi pertanyaan/ide & 5.63 \\
7 & Menulis yang relevan dengan KBM & 7.70 \\
8 & Merangkum pembelajaran & 6,67 \\
\hline
\end{tabular}

Berdasarkan Tabel 4.6 tampak bahwa aktivitas guru yang paling dominan pada siklus II adalah membimbing dan mengamati siswa dalam menentukan konsep yaitu $24.00 \%$, memberikan umpan balik yaitu 16,67\%, kemudian menyampaikan langkah-langkah strategis dan memberi umpan balik yaitu masing-masing 11,67\%. Sedangkan untuk aktivitas siswa yang paling dominan pada siklus II adalah bekerja dengan sesama anggota kelompok, mendengarkan penjelasan guru, membaca buku, dan diskusi antar siswa/antara siswa dengan guru yaitu $19.79 \%, 17.81 \%, 14.26 \%$ dan $13.96 \%$.

Berikutnya adalah rekapitulasi hasil tes formatif siswa terlihat pada tabel berikut.

Tabel 4.7. Rekapitulasi Hasil Tes Siklus II

\begin{tabular}{|l|l|l|}
\hline No & Uraian & Hasil Siklus II \\
\hline
\end{tabular}




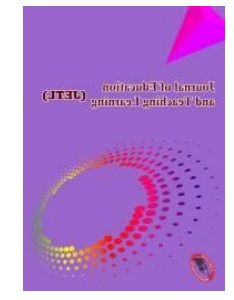

Journal of Education and Teaching Learning (JETL)

Journal of Education and Teaching Learning, 2019

Vol. 1, No. 2, 50-67

Journal Homepage: http://pusdikra-publishing.com/index.php/jetl

\begin{tabular}{|l|l|c|}
\hline 1 & Nilai rata-rata tes formatif & 76,03 \\
2 & Jumlah siswa yang tuntas belajar & 41 \\
3 & Persentase ketuntasan helaiar & 7938 \\
\hline
\end{tabular}

Tabel 4.7 diperoleh nilai rata-rata prestasi belajar siswa adalah 76,03 dan ketuntasan belajar mencapai 79,38\% atau ada 41 siswa dari 45 siswa sudah tuntas belajar. Hasil ini menunjukkan bahwa pada siklus II ini ketuntasan belajar secara klasikal telah megalami peningkatan sedikit lebih baik dari siklus I. Adanya peningkatan hasil belajar siswa ini karena setelah guru menginformasikan bahwa setiap akhir pelajaran akan selalu diadakan tes sehingga pada pertemuan berikutnya siswa lebih termotivasi untuk belajar. Selain itu siswa juga sudah mengerti apa yang dimaksudkan dan diinginkan guru dengan menerapkan metode pembelajaran demonstrasi.

Refleksi merupakan tahap yang telah terlaksana dengan baik maupun yang masih kurang baik dalam proses belajar mengajar dengan penerapan pembelajaran demonstrasi. Dari data-data yang telah diperoleh dapat diuraikan sebagai berikut: 1)Selama proses belajar mengajar guru telah melaksanakan semua pembelajaran dengan baik. Meskipun ada beberapa aspek yang belum sempurna, tetapi persentase pelaksanaannya untuk masing-masing aspek cukup besar. 2) Berdasarkan data hasil pengamatan diketahui bahwa siswa aktif selama proses belajar berlangsung. 3) Kekurangan pada siklus-siklus sebelumnya sudah mengalami perbaikan dan peningkatan sehingga menjadi lebih baik. 4) Hasil belajar siswa pada siklus II mencapai ketuntasan.

Selanjutnya dilakukan Revisi Pelaksanaan, Pada siklus II guru telah menerapkan pembelajaran demonstrasi dengan baik dan dilihat dari aktivitas siswa serta hasil belajar siswa pelaksanaan proses belajar mengajar sudah berjalan dengan baik. Maka tidak 


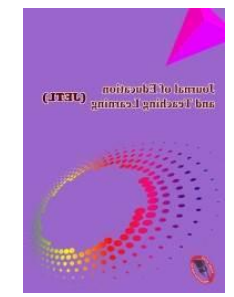

\section{Journal of Education and Teaching Learning (JETL) \\ Journal of Education and Teaching Learning, 2019 \\ Vol. 1, No. 2, 50-67 \\ Journal Homepage: http://pusdikra-publishing.com/index.php/jetl}

diperlukan revisi terlalu banyak, tetapi yang perlu diperhatikan untuk tindakan selanjutnya adalah memaksimalkan dan mepertahankan apa yang telah ada dengan tujuan agar pada pelaksanaan proses belajar mengajar selanjutnya penerapan pembelajaran demonstrasi dapat meningkatkan proses belajar mengajar sehingga tujuan pembelajaran dapat tercapai.

\section{PEMBAHASAN}

Berdasarkan Ketuntasan Hasil belajar Siswa Melalui hasil penelitian ini menunjukkan bahwa pembelajaran demonstrasi memiliki dampak positif dalam meningkatkan prestasi belajar siswa. Hal ini dapat dilihat dari semakin mantapnya pemahaman siswa terhadap materi yang disampaikan guru (ketuntasan belajar meningkat dari siklus I dan II) yaitu masing-masing 69,57\% dan 79,38\%. Pada siklus III ketuntasan belajar siswa secara klasikal telah tercapai. Kemampuan Guru dalam Mengelola Pembelajaran Kemampuan Guru dalam Mengelola Pembelajaran. Aktivitas Guru dan Siswa Dalam Pembelajaran

Berdasarkan analisis data, diperoleh aktivitas siswa dalam proses pembelajaran PKN pada pokok bahasan Perilaku kemerdekaan mengeluarkan pendapat dengan metode pembelajaran demonstrasi yang paling dominan adalah bekerja dengan menggunakan alat/media, mendengarkan/memperhatikan penjelasan guru, dan diskusi antar siswa/antara siswa dengan guru. Jadi dapat dikatakan bahwa aktivitas siswa dapat dikategorikan aktif. Sedangkan untuk aktivitas guru selama pembelajaran telah melaksanakan langahlangkah pembelajaran demonstrasi dengan baik. Hal ini terlihat dari aktivitas guru yang muncul di antaranya aktivitas membimbing dan mengamati siswa dalam mengerjakan kegiatan LKS/menemukan konsep, menjelaskan/melatih menggunakan alat, memberi umpan balik/evaluasi/tanya jawab dimana presentase untuk aktivitas di atas cukup besar. 


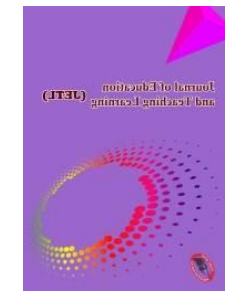

\section{Journal of Education and Teaching Learning (JETL) \\ Journal of Education and Teaching Learning, 2019 \\ Vol. 1, No. 2, 50-67 \\ Journal Homepage: http://pusdikra-publishing.com/index.php/jetl}

\section{KESIMPULAN}

berdasarkan penelitian yang dilakukan maka diperoleh hasil pada Siklus I nilairatarata prestasi belajar siswa adalah 70,00 dan ketuntasan belajar mencapai siklus $67,57 \%$ atauada 25 siswa dari35 siswa sudah tuntas belajar. Siklus II nilai rata-rata prestasi belajar siswa adalah 77,03dan ketuntasan belajar mencapai78,38\%atau ada 29 siswa dari35 siswa sudah tuntasbelajarSiklus III nilai rata-rata tes formatif sebesar83,24dan dari35 siswa yang telah tuntas sebanyak33 siswa dan siswa belum mencapai ketuntasan belajar. Melalui hasil peneilitianini menunjukkan bahwa pembelajaran penemuan (discovery) memilikidampak positif dalam meningkatkan prestasi belajar siswa.Hal ini dapat dilihat dari semakin mantapnya pemahaman siswa terhadap materiyang disampaikan guru(ketuntasan belajar meningkat dari sklusI,II,danIII)yaitu masing-masing 67,57\%,78,38\%,dan89,19\%.Pada siklus III ketuntasan belajar siswa secara klasikal telah tercapai.

\section{DAFTAR PUSTAKA}

Arikunto, Suharsimi. 2001.Dasar-dasar Evaluasi Pendidikan. Jakarta: Bumi Aksara. Arikunto, Suharsimi. 2002. Prosedur Penelitian Suatu Pendekatan Praktek.Jakarta:RineksaCipta.

Combs.Arthur. W.1984.The Profesional Education of Teachers. Allinand Bacon, Inc. Boston.

Dahar, R.W. 1989.Teori-teori Belajar.Jakarta: Erlangga.

Departemen Pendidiakan dan Kebudayaan, 1994.Petunjuk Pelaksanaan Proses Belajar Mengajar.Jakarta. Balai Pustaka.

Djamarah, SyaifulBahri. 2002.Strategi Belajar Mengajar. Jakarta: Rineksa Cipta. Djamarah.

Fadhli, M. (2020). Sistem Penjaminan Mutu Internal Dan Ekstenal Pada Lembaga Pendidikan Tinggi. AL-TANZIM: Jurnal Manajemen Pendidikan Islam, 4(2), 53-65. https://doi.org/10.33650/al-tanzim.v4i2.1148

SyaifulBahri. 2002.Psikologi Belajar. Jakarta:Rineksa Cipta. 
Journal of Education and Teaching Learning (JETL)

Journal of Education and Teaching Learning, 2019

Vol. 1, No. 2, 50-67

Journal Homepage: $h$ ttp://pusdikra-publishing.com/index.php/jetl

Hamalik, Oemar. 1994.Metode Pendidikan.Bandung: Citra Aditya Bakti.

Hamalik,Oemar. 2000. Psikologi Belajar dan Mengajar. Bandung: Sinar Baru Algesindo.

Hasibuan.J.J. dan Moerdjiono. 1998. Proses Belajar Mengajar. Bandung: Remaja Rosdakarya.

KBBI. 1996. Edisi Kedua. Jakarta: Balai Pustaka.

Kemmis, S. dan Mc. Taggart, R. 1988. The Action Research Planner. Victoria Dearcin University Press.

Margono. 1997. Metodologi Penelitian Pendidikan. Jakarta: Rineksa Cipta.

Ngalim, Purwanto M. 1990. Psikologi Pendidikan. Bandung: Remaja Rosdakarya.

Nur, Moh. 2001. Pemotivasian Siswa untuk Belajar. Surabaya. University Press. Universitas Negeri Surabaya.

Poerwodarminto.1991. Kamus Umum Bahasa Indonesia. Jakarta: Binallmu.

Purwaningsari. 2002. Pengaruh Penerapan Model Pembelajaran Penemuan Terbimbing melalui Model Eksperimen terhadap Prestasi belajar Fisika pada Siswa SMU Muhammadiyah I Nganjuk. Skripsi yang tidak dipublikasikan. Universitas Negeri Surabaya.

Purwanto, N. 1988.Prinsip-prinsip dan Teknis Evaluasi Pengajaran. Bandung: Remaja RosdaKarya.

Rustiyah, N.K. 1991.Strategi Belajar Mengajar. Jakarta: Bina Aksara.

Sardiman, A.M. 1996. Interaksi dan Motivasi Belajar Mengajar. Jakarta: Bina Aksara.

Soetomo. 1993. Dasar-dasar Interaksi Belajar Mengajar. Surabaya Usaha Nasional.

Sukidin, dkk. 2002. Manajemen Penelitian Tindakan Kelas. Surabaya: Insan Cendekia.

Suryosubroto. 1997.Proses Belajar Mengajar di Sekolah. Jakarta:PT. Rineksa Cipta.

Syafi'udin. 2002. Penerapan Pendekatan Konstruktivis dengan menggunakan Metode Penemuan untuk Meningkatkan Prestasi Belajar Siswa KelasI MTsN Denanyar. Skripsi yang tidak dipublikasikan Universitas Negeri Surabaya.

Syah, Muhibbin. 1995. Psikologi Pendidikan, Suatu Pendekatan Baru. Bandung: Remaja Rosdakarya.

Usman, Uzer. 2000. Menjadi Guru Profesional. Bandung: PT. Remaja Rosdakarya. 


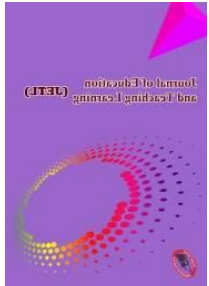

Journal of Education and Teaching Learning (JETL)

Journal of Education and Teaching Learning, 2019

Vol. 1, No. 2, 50-67

Journal Homepage: http://pusdikra-publishing.com/index.php/jetl

Zaini, M. F. (2019). The Implementation Of Learning Management In Class VIII Madrasa

Tsanawiyah Islamiyah (Mts) Ypi Batangkuis. International Conference on Islamic Educational Management (ICIEM). 